\title{
Designing and Manufacturing of a Non Thermal Milk Pasteurizer Using Electrical Field
}

\author{
Asaad Rehman Saeed Al-Hilphy \\ Department of Food Science, Agriculture College, Basrah University Basrah, Iraq
}

Received 2013-07-09, Revised 2013-08-05; Accepted 2013-08-21

\begin{abstract}
Using of traditional milk pasteurization methods caused fouling by heat, particularly rapid pasteurization by ohmic heating at 220 volts resulted protein denaturation, when milk holding of $15 \mathrm{sec}$ under ohmic heating at $72^{\circ} \mathrm{C}$. So to control these properties a Non-thermal treatment by different electrical fields at 20, 27.5, 55 $\mathrm{V} / \mathrm{cm}(80,110,220 \mathrm{~V}, \mathrm{AC})$ and quickly milk pass between poles in a long narrow tube during less than 0.8 sec. The study focused on applying different electrical fields in milk pasteurization as a non thermal treatment and calculates the electrical conductivity, viscosity of milk, holding time, productivity, performance coefficient and measurement of final output milk temperature at $20,27.5,55 \mathrm{~V} / \mathrm{cm}, \mathrm{pH}$, acidity, chemical composition, microbiological characteristics and storage periods for the pasteurized milk. The obtained results indicated that the final output milk temperature was reached $40^{\circ} \mathrm{C}$ and electrical conductivity was increased and viscosity was decreased with increasing temperature and productivity and performance coefficient were $1140 \mathrm{~L} / \mathrm{h}, 99.8$ respectively. More over pasteurized milk chemical composition and it's $\mathrm{pH}$ were not influenced in electrical field. Resulting of bacteria elimination and alkaline phosphatase was inhibited by the electrical field as well. The results showed that the electrical field $55 \mathrm{~V} / \mathrm{cm}$ is better than other electrical fields $(20,27.5 \mathrm{~V} / \mathrm{cm})$.
\end{abstract}

Keywords: Milk Pasteurization, Electrical Field, Non-Thermal Treatment

\section{INTRODUCTION}

Manufacture of virtually all milk and dairy products involves heat treatment, which is mainly aimed to kill microorganisms and inactivation of enzymes, or to achieving some other, mainly chemical, changes. This depends on the intensity of the treatment, i.e., the combination of temperature and duration of heating. Consequently heat treatment may also cause undesirable changes, although desirability may depend on the product involved or on it's intended use. Such on browning development of a cooked flavor loss of nutritional quality inactivation of bacterial inhibitors and impairment of rennet ability (Walstra et al., 1999).

Pasteurization is a mild process, designed to inactivate the major pathogenic and spoilage bacteria found in raw milk. It should produce minimal chemical, physical and organoleptic changes in the product (Smit, 2003). Range of thermal treatments were used to reduce the bacterial population of milk, which include thermisation, batch and HTST pasteurization, high temperature pasteurization (ESL), UHT treatment and incontainer sterilization (Kelly et al., 2006). As well as microwave pasteurization (Wang and Sastry, 2003; Albert et al., 2009; Al-Hilphy et al., 2010). Virgiliu et al. (2007) stated that the next methods of pasteurization are used may be slow pasteurization or low pasteurization at the temperature of $62-65^{\circ} \mathrm{C} / 30 \mathrm{~min}$, respective $20 \mathrm{~min}$, where as midst pasteurization or shorten pasteurization is performed at the temperature of $72-78^{\circ} \mathrm{C} / 15 \mathrm{sec}$. known as, High pasteurization or instantaneous pasteurization (HTST) is performed between $85-90^{\circ} \mathrm{C}$, for a few sec. followed by sudden cooling at $10^{\circ} \mathrm{C}$.

Ther are several non-thermal treatments can be used to destroy microorganisms in foods which including high-pressure treatment, pulsed electric field technology, ultra sonication, centrifugation and microfiltration; however, only the last two technologies 
are used commercially for milk (Datta and Deeth, 2002; Deeth and Datta, 2002). There is other milk pasteurization method, its called solar milk pasteurization, in this method the solar energy was used to milk pasteurization (AlRubaiy, 2010). Ohmic heating is a thermal process in which heat is internally generated by the passage of Alternating electrical Current (AC) through a body such as a food system that serves as an electrical resistance (Shirsat et al., 2004). The main advantages of ohmic processing are the rapid and relatively uniform heating achieved (Zareifard et al., 2003). Direct ohmic heating has problems with fouling and corrosion. Fouling creation of milk was studied by Ayadi et al. (2004a).

In fact using ohmic heating for milk pasteurization at $72^{\circ} \mathrm{C}$ for $15 \mathrm{sec}$ with 220 volt $\mathrm{AC}$ produce low quality pasteurized milk because of the whey proteins are became denatured and occur reaction between poles and milk and constituted deposits on the poles and fouling (Muhsin, 2012). The aim of this study is to milk pasteurization by different electrical fields at 20, 27.5, 55 $\mathrm{V} / \mathrm{cm}(80,110,220 \mathrm{~V}, \mathrm{AC})$ as a non-thermal treatment to improvement pasteurized milk quality.

\section{MATERIALS AND METHODS}

\subsection{Apparatus of Milk Pasteurization by Electrical field}

The apparatus was designed and manufactured in the Food Engineering Laboratory, Faculty of Agriculture, University of Basrah, Iraq. The device consists of a reservoir made of stainless steel 316 double wall. It's capacity 25 liters, pump its discharge 20 liters $/ \mathrm{min}$ and a heat plastic tube with internal diameter $1 \mathrm{~cm}$ and a length of $3 \mathrm{~m}$. Its fixed on it 20 electrodes and the distance between the electrodes of $4 \mathrm{~cm} \mathrm{It} \mathrm{is} \mathrm{made} \mathrm{of} \mathrm{stainless} \mathrm{steel} \mathrm{316,} \mathrm{electrode}$ diameter $0.3 \mathrm{~cm}$ and $2 \mathrm{~cm}$ long Fig. (1 and 2).

This design doesn't need holding tube, thermal valve, heat exchanger and high pressure pump, but it depends on the electrical field (AC) generated between electrical poles. The apparatus is doesn't has complicated parts and it's parts are simple as tank, heat plastic pipe, stainless steel electrical poles, pump and valve. Electrical conductivity is calculated according to Equation (1) (Wang and Sastry, 1993; Icier et al., 2008):

$$
\sigma=\frac{\mathrm{IL}}{\mathrm{VA}}
$$

I: current (A), L: distance between poles (m), V: voltage $(\mathrm{V})$, A: section area $\left(\mathrm{m}^{2}\right)$ and $\sigma$ : electrical conductivity $(\mathrm{S} / \mathrm{m})$.

Time of the holding milk in the apparatus is calculated from the Equation (2) (Maroulis and Saravacos, 2003):

$\mathrm{t}=\frac{\rho A L_{d}}{\mathrm{~m}}$

$\mathrm{t}$ : holding time $(\mathrm{sec}), \mathrm{A}$ : section area $\left(\mathrm{m}^{2}\right), \mathrm{L}_{\mathrm{d}}$ : pipe length $(\mathrm{m})$ and $\mathrm{m}$ : milk mass flow (kg/.sec.).

The apparatus productivity was calculated through the total milk output from apparatus at specifying time $(\mathrm{L} / \mathrm{h})$.

While system Performance Coefficient (SPC) is calculated from Equation $(3,4)$ (Icier and Ilicali, 2004; 2005):

$\mathrm{SPC}=\frac{\mathrm{Q}_{\mathrm{t}}}{\mathrm{E}_{\mathrm{g}}}$

Where:

$$
\begin{aligned}
& \mathrm{E}_{\mathrm{g}}=\mathrm{Q}_{\mathrm{t}}+\mathrm{E}_{\text {loss }}=\sum \Delta \mathrm{VIt} \\
& \mathrm{Q}_{\mathrm{t}}=\mathrm{mc}_{\mathrm{p}}\left(\mathrm{T}_{\mathrm{in}}-\mathrm{T}_{\mathrm{w}}\right)
\end{aligned}
$$

$\mathrm{M}$ : mass $(\mathrm{kg}), \mathrm{T}_{\mathrm{w}}$ : final temperature $\left({ }^{\circ} \mathrm{C}\right), \mathrm{T}_{\mathrm{in}}$ : primary temperature $\left({ }^{\circ} \mathrm{C}\right), \mathrm{E}_{\mathrm{g}}$ : amount of given energy $(\mathrm{J})$ and $\mathrm{Q}_{\mathrm{t}}$ : the amount of taken heat $(\mathrm{J})$.

In which the electric field strength, $\mathrm{E}(\mathrm{V} / \mathrm{cm})$, is calculated by Equation (5) (Floury et al., 2006):

$\mathrm{E}=\frac{\mathrm{V}}{\mathrm{d}}$

where, $\mathrm{d}$ is the inter-electric distance $(\mathrm{cm})$.

The glass Ostwald (Size A) is used in estimating the viscosity of raw milk and pasteurized milk in the electric field by the method of Sathe and Salunkhe (1981) to estimate the viscosity. By using of tables Weast and Melvin (1982-1983) for the extraction of specific gravity and viscosity of water at different temperatures are calculated through out the Equation 6:

$\frac{\mathrm{v}_{1}}{\mathrm{v}_{2}}=\frac{\rho_{1} \mathrm{t}_{1}}{\rho_{2} \mathrm{t}_{2}}$ 


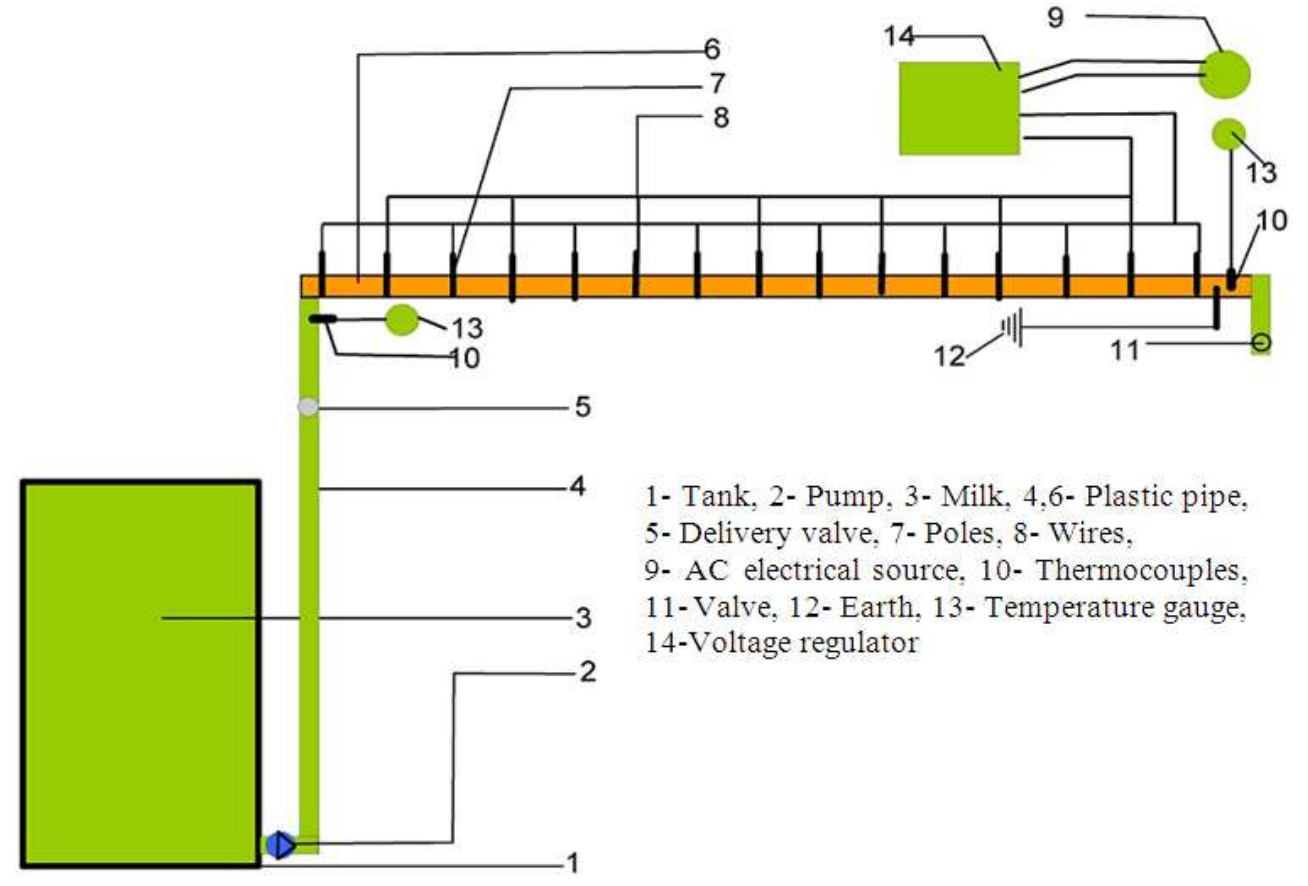

Fig. 1. Schematic diagram of milk pasteurizer by electrical field

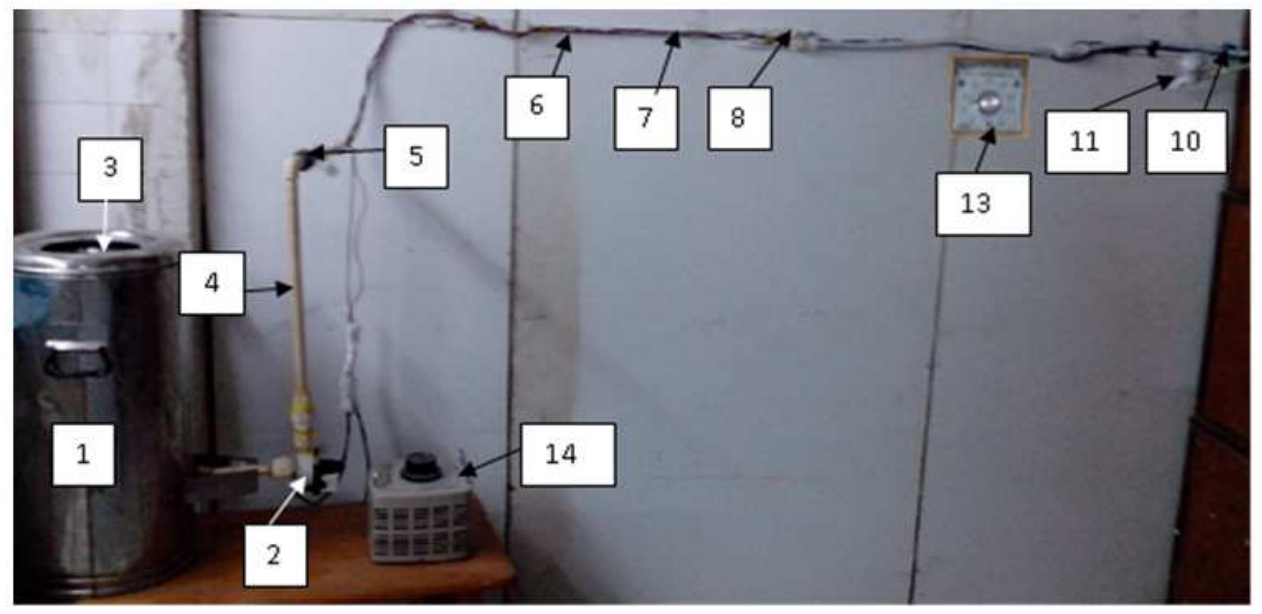

Fig. 2. Photograph of milk pasteurizer by electrical field

The milk density was determined by the method that mentioned by Pearson (1976) by using Pyknometer.

Chemical tests included determination of moisture where estimated percentage of moisture was recorded according to the method described in the Williams (1984). Each of protein, fat, lactose and ash are estimated by the method of Egan et al. (1988). Acidity and $\mathrm{pH}$ of the raw milk and pasteurized milk are measured and then after the storage period amounting twenty one days, according to the method applied by Egan et al. (1988). Phosphatase enzyme in the raw and pasteurized milk are detected according to the enzyme method that included commercial treaty (kit) that described in the (Ryan et al., 2000).

Microbiological tests are conducted on raw milk and pasteurized and after a period of storage for twenty one 
days casting method are used to calculate the number of dishes microbiology in milk samples (Al-Sharifi and Muhammed, 1992). Estimation included total bacteria count and estimate yeasts and molds, staphylococcus.

Statistical analysis: One way ANOVA and post-hoc comparison statistical analyses which performed by using SPSS 11.0 statistical packages are applied (SPSS, 2001).

\section{RESULTS AND DISCUSSION}

Electrical conductivity is the measurement of a substance transmits electric charge, expressed in Siemens per meter, which is a ratio of the substance density to electric field strength and is affected by the chemical composition of a substance (Ande, 2008). Resuts showed that the electrical conductivity was increased with increasing milk temperature for all electrical fields $(55,27.5$ and $20 \mathrm{~V} / \mathrm{cm})$ respectivily. As evident from Fig. 3 which show the relationship between electrical conductivity and temperature of milk at defferent electrical fields. When temperature were 10 and $40^{\circ} \mathrm{C}$, the electrical conuctivity were 0.798 and $0.858 \mathrm{~S} / \mathrm{m}$ respectivly at $55 \mathrm{~V} / \mathrm{cm}$. The increasing in the electrical conductivity with temperature is caused by to the increasing of current with increasing temperature, as Kong et al. (2008) whom stated that the current increase with increasing temperature. Data in Fig. 3 showed the relationship between electrical conductivity and temperature of milk was linear equation for all electrical fields such as $\sigma=0.002 \mathrm{~T}+0.7765$ at 55 $\mathrm{V} / \mathrm{cm}$ and determination coeffecient is $\mathrm{R}^{2}=0.997$. The dependance of the electric conductivity of milk on temperature is very imporant and the relationship between them is linear equation as stated by (Uemura and Isobe, 2002; Novy and Zitny, 2005). Consequantly, the results showed that electrical conductivity was increased with increasing electrical field.

On the other hand the results showed in Fig. (4) that the viscosity of milk decreased with increasing temperature and this because the increase in temperature leads to lower milk fatty blocs responsible for the high viscosity of milk. The relationships between viscosity and temperature is first-order equations for all electrical fields such as in the $55 \mathrm{~V} / \mathrm{cm}$ the relationship between temperature and viscosity is $v$ $=-3 \mathrm{E}-05 \mathrm{~T}+0.002$, where $10 \leq \mathrm{T} \leq 40$. The coefficient of determination $\mathrm{R}=0.9963$. Results also showed that the differences in viscosity between electrical fields are not significant at all temperatures.
Milk density was reduced with increasing milk temperature as shown in Fig, 5 this reducing due to the rising of milk temperature up to $40^{\circ} \mathrm{C}$ as Muhsin (2012) stated that milk density reduced with increasing temperature and electrical field. The results also showed that the differences in the density between electrical fields were not significant at all temperatures.

Final Output milk temperature was $40 \pm 1.49{ }^{\circ} \mathrm{C}$ at 55 $\mathrm{V} / \mathrm{cm}$ and $35 \pm 1.39$ at $20 \mathrm{~V} / \mathrm{cm}$ significantly reduced by reducing electrical field, this reducing is due to reducing electrical coductivity. that temperature $\left(40^{\circ} \mathrm{C}\right)$ is very necessary in milk filling and packaging processing (Table 1) The results showed that the holding time doesn't significantly affected by electrical field. The holding time is $0.708 \pm 0.0042(\mathrm{sec})$ at $55 \mathrm{~V} . \mathrm{cm}$, which to prevent formation of fouling and deposits on the poles because the high voltage (220 volt) cause whey protein denaturation and milk overheating closed to poles and poles corrosion. This results was agreed with Ayadi et al. (2004b). So there is a strong effect of electrode material and significant effect of the current density, numerical simulation showed that even a relative thin layer of deposits can be over heated and could accelerate change in whey proteins leading to the final growing phase of fouling (Stanc and Zinty, 2005).

The obtained results showed that apparatus productivity was not significantly affected by electrical field and the productivity is $1140 \pm 1.31(1 / \mathrm{h})$ at $55 \mathrm{~V} / \mathrm{cm}$, which it's refers to high productivity. In Basrah Province, the farms are very far away from dairy factories and in the very hot summer, this requires to fast pasteurization processes for milk in order to prevent spoilage, with simple apparatus operation design.

System Performance Coefficient is defined by using the energy given to the system and taken up by the sample (Icier and Ilicali, 2004). low energy loss would indicate a system with a high performance.SPC value giving the ratio between the heat taken by the milk and energy given to the system. Data in Table 1 showed that SPC doesn't significant affected by electrical field. SPC was $99.8 \pm 0.015$ at $55 \mathrm{~V} / \mathrm{cm}$.

The results in Table 2 has showed a slight reduction in moisture content (\%), fat, lactose and ash when milk pasteurized by electrical field. This decline due to the slight rise in temperature which caused of the low percentage of fat in pasteurized milk may be due to some fatty globule adhesion with device in the pipeline because of the non-homogenized milk. All of the protein, acidity and $\mathrm{pH}$ are not significantly affected by the electrical field pasteurization process, as well. 
Asaad Rehman Saeed Al-Hilphy / American Journal of Agricultural and Biological Sciences 8 (3): 204-211, 2013

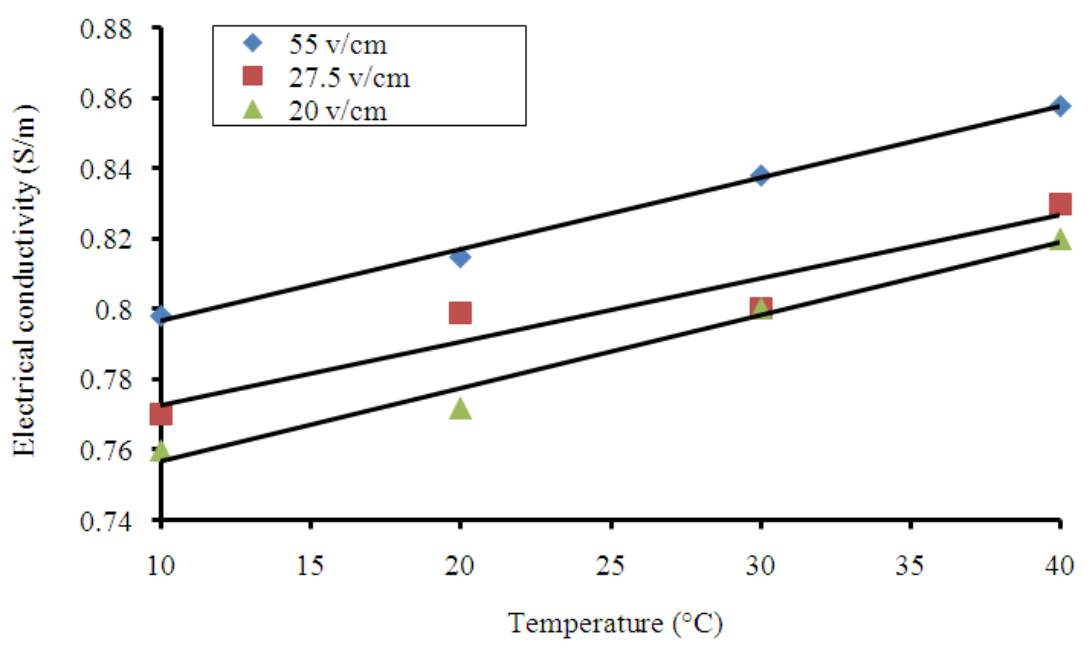

Fig. 3. Electrical conductivity vs. milk temperature at different electrical field

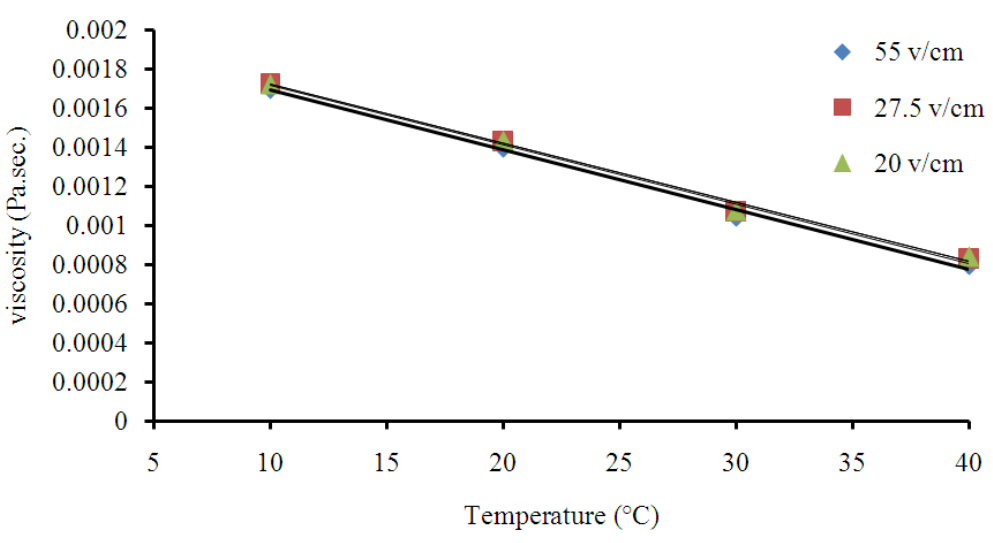

Fig. 4. Viscosity vs. temperature of milk at electrical field pasteurization

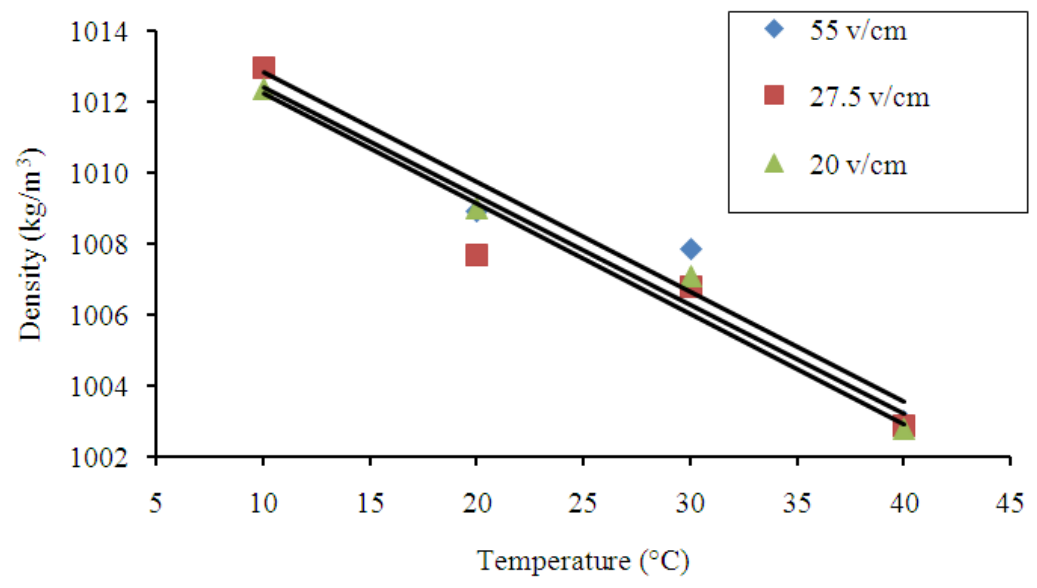

Fig. 5. Density vs. temperature of pasteurized milk by electrical field 


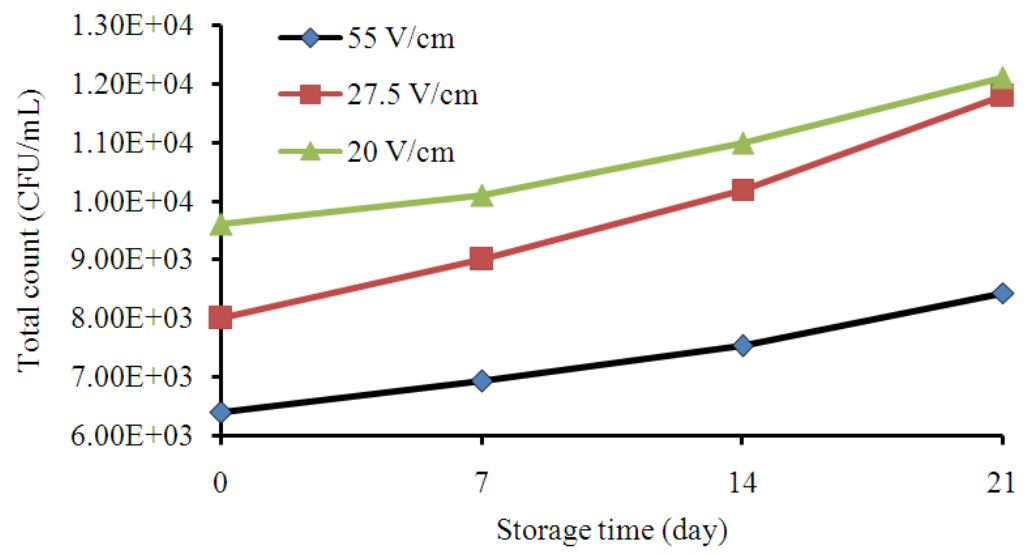

Fig. 6. Total microbial count vs. storage time at different electrical field

Table 1. Final output milk temperature, staying time, productivity and system performance coefficient of apparatus

\begin{tabular}{lllll}
\hline $\begin{array}{l}\text { Electrical } \\
\text { field }(\mathrm{V} / \mathrm{cm})\end{array}$ & $\begin{array}{l}\text { Final Output } \\
\text { milk temperature }\end{array}$ & Holding time $(\mathrm{sec})$. & $\begin{array}{l}\text { Productivity } \\
(\mathrm{l} / \mathrm{h})\end{array}$ & $\begin{array}{l}\text { System } \\
\text { performance coefficient }\end{array}$ \\
\hline 55 & ${ }^{\mathrm{a}} 40 \pm 1.49$ & ${ }^{\mathrm{a}} 0.708 \pm 0.0042$ & ${ }^{\mathrm{a}} 1140.2 \pm 1.31$ & ${ }^{\mathrm{a}} 99.8 \pm 0.015$ \\
27.5 & $\mathrm{~b}^{\mathrm{b}} 7 \pm 1.68$ & ${ }^{\mathrm{a}} 0.707 \pm .0051$ & ${ }^{\mathrm{a}} 1139.4 \pm 1.28$ & ${ }^{\mathrm{a}} 98.96 \pm 0.018$ \\
20 & ${ }^{\mathrm{c}} 35 \pm 1.39$ & ${ }^{\mathrm{a}} 0.706 \pm 0.008$ & ${ }^{\mathrm{a}} 1139.2 \pm 1.5$ & ${ }^{\mathrm{a}} 98.90 \pm 0.013$ \\
\hline
\end{tabular}

Table 2. Chemical composition (\%), acidity (\%) and pH for raw and pasteurized milk by electrical field

\begin{tabular}{|c|c|c|c|c|c|c|c|}
\hline $\begin{array}{l}\text { Electrical } \\
\text { field }(V / \mathrm{cm})\end{array}$ & $\begin{array}{l}\text { Moisture } \\
\text { content }\end{array}$ & Fat & Protein & Lactose & Ash & Acidity & $\mathrm{pH}$ \\
\hline Raw milk & $86.4 \pm 0.385$ & $3.7 \pm 0.007$ & $3.7 \pm 0.006$ & $5.6 \pm 0.012$ & $0.59 \pm 0.006$ & $0.15 \pm 0.004$ & $6.6 \pm 0.007$ \\
\hline 55 & $86.01 \pm 0.480$ & $3.6 \pm 0.028$ & $3.7 \pm 0.035$ & $5.5 \pm 0.028$ & $0.58 \pm 0.001$ & $0.15 \pm 0.003$ & $6.6 \pm 0.007$ \\
\hline 27.5 & $86.3 \pm 0.510$ & $3.6 \pm 0.009$ & $3.6 \pm 0.06$ & $5.7 \pm 0.04$ & $0.60 \pm 0.003$ & $0.14 \pm 0.005$ & $6.6 \pm 0.005$ \\
\hline 20 & $86.4 \pm 0.61$ & $3.2 \pm 0.01$ & $3.58 \pm 0.03$ & $5.6 \pm 0.05$ & $0.59 \pm 0.004$ & $0.15 \pm 0.003$ & $6.59 \pm 0.009$ \\
\hline
\end{tabular}

Table 3. Microbiological data for raw and pasteurized milk by electrical field

\begin{tabular}{lllllll}
$\begin{array}{l}\text { Electrical } \\
\text { field }(\mathrm{V} / \mathrm{cm})\end{array}$ & $\begin{array}{l}\text { Total count } \\
(\mathrm{CFU} / \mathrm{ml})\end{array}$ & Enterobactor & E-coli & staphylococcus & $\begin{array}{l}\text { Yeasts and } \\
\text { molds count }\end{array}$ & $\begin{array}{l}\text { Alkaline } \\
\text { phosphatase enzyme }\end{array}$ \\
\hline Raw milk & $154 \times 10^{3}$ & $6 \times 10^{2}$ & $86 \times 10^{3}$ & $61 \times 10^{3}$ & - & + \\
55 & $64 \times 10^{2}$ & 0 & 0 & 0 & - & - \\
27.5 & $80 \times 10^{2}$ & $2 \times 10^{1}$ & 0 & $1 \times 10^{2}$ & - & + \\
20 & $96 \times 10^{2}$ & $9 \times 10^{1}$ & 0 & $3 \times 10^{2}$ & - & + \\
\hline
\end{tabular}

Results in Table 3 showed the total count bacteria in raw milk was $154,000 \mathrm{CFU} / \mathrm{ml}$ The number of colonies after a pasteurization process by electrical field at 6400 , 8000 and $9600 \mathrm{CFU} / \mathrm{ml}$ at 55, 27.5 and $20 \mathrm{~V} / \mathrm{cm}$ respectively. This results was less than the minimum Iraqi standard specification, which stated that the total count bacteria in pasteurized milk of good quality is 10000 and $50000 \mathrm{CFU} / \mathrm{mL}$ with acceptable quality milk. Moreover, these results are less than the minimum of the Australian standard specification for the year 2007, which showed that the total count of pasteurized milk be between 50000-100000 CFU/mL. Coliform bacteria
Enterobactor task in milk as the presence in pasteurized milk evidence of the inefficiency of the pasteurization process. The results also showed that total count bacteria Enterobactor in raw milk was $600 \mathrm{CFU} / \mathrm{mL}$ and the number of colonies are reduced to zero after a pasteurization process at electrical field of $55 \mathrm{~V} / \mathrm{cm}$, this results are considered less than Iraqi and Australian standard specification which showed that the total number of coliform Enterobactor in pasteurized milk must be at least $10 \mathrm{CFU} / \mathrm{ml}$. While the number of colonies were reduced to 20 and $90 \mathrm{CFU} / \mathrm{ml}$ at electrical fields 27.5 and $20 \mathrm{~V} / \mathrm{cm}$ respectivel. 
The presence of fecal bactria in the milk denote contaminated animal feces and therefore their presence in pasteurized milk evidence of the inefficiency of the pasteurization process. Also, total count for E-coli bacteria in raw milk is 86000 and number of colonies are reduced to zero after a pasteurization process by electrical field and these results are in accordance with Iraqi and Australian standard specification. Staphylococcus is reduced to zero at electrical field 55 $\mathrm{V} / \mathrm{cm}$. as well. Results indicated that and presence of alkaline phosphatase in raw milk and its absence in the electrical field pasteurized milk and all living cells contain cell membrane. These membranes are comprised of lipids (fatty molecules) and proteins (Alberts et al., 2007). Electroporation occurs because the cell membrane has a specific dielectric strength, which can be exceed by the electric field. The dielectric strength of a cell membrane is related to the amount of lipids (acting as an insulator) present in the membrane itself. The formed pores can vary in size depending on the strength of the electric field and can reseal after a short period of time. Excessive exposure causes cell death due to the leakage of intracellular components through the pores (Lee and Yoon, 1999). Therefore electroporation is highly damaging to a cell.

Results showed the absence of any growth of yeasts and molds before and after the process of electrical field pasteurization, as well as.

For the impact of the storage period for pasteurized milk Sterile taken samples and under hygienic conditions has been archived sample at room temperature for two days as observed undesirable changes in milk as a result of the pollution. The sec sample was preserved in the refrigerator at $4^{\circ} \mathrm{C}$ for a period of 21 days has been conducted tests the microbiological every seven days. The results of the impact of storage periods for pasteurized milk indicated the minimum standard specification Iraqi and Australian for counting bacteria total since reached after 7,14 and 21 days of storage 6925,7534 and $8435 \mathrm{CFU} / \mathrm{ml}$ at $55 \mathrm{~V} / \mathrm{cm}$. As for the two types of coliform bacteria staphylococcus, yeasts and molds did not show any growth which shows the efficiency of the pasteurization process (Fig. 6). The total microbial count at $55 \mathrm{~V} / \mathrm{cm}$ was less than at 27.5 and $20 \mathrm{~V} / \mathrm{cm}$ and located with in the minimum standard specification Iraqi and Australian specification.

\section{CONCLUSION}

Throughout the results of the study, can pasteurization of milk by electrical field at $55 \mathrm{~V} / \mathrm{cm}(220$ $\mathrm{V}, \mathrm{AC}$ ) and milk temperature are not more than $40^{\circ} \mathrm{C}$.
The device proved highly efficient in eliminating microorganisms and pasteurized milk storage good results. The chemical composition and acidity are not affected by electrical field. Pasteurized milk quality was improved. Alkaline phosphatase was absent in the pasteurized milk at $55 \mathrm{~V} / \mathrm{cm}$ but it's present in the pasteurized milk at 27.5 and $20 \mathrm{~V} / \mathrm{cm}$. Stopping use the electrical fields 27.5 and 20 $\mathrm{V} / \mathrm{cm}$ for milk pasteurization in this study.

\section{REFERENCES}

Albert, C.S., Z. Moki, Z. Csapo-Kiss and J. Csapo, 2009. The effect of microwave pasteurization on the composition of milk. Acta Univ. Sapientiae, Alim., 2: 153-165.

Alberts, B., A. Johnson, J. Lewis, M. Raff and K. Robert et al., 2007. Molecular Biology of the Cell. 5th Edn., Garland Science, ISBN-10: 0815341059, pp: 1392.

Al-Hilphy, A.R.S., A.B.R. Al-Temimi and A.A.AlSeraih, 2010. Milk pasteurization by microwave and study its chemical and microbiological characteristics during different storage times. Basrah. Res. J.

AlRubaiy, H.H.M., 2010. Designing and manufacturing milk pasteurization device by solar energy and studying its efficiency. MSc. Thesis, Food Sciences, Agriculture College, Basrah University.

Al-Sharifi, H.R. and S.H. Muhammed, 1992. A Practical Dairy Microbiology. Dar Alhikmah Press. 1st Edn., Basrah. Iraq, ISBN-10: 0471227560 pp: 784.

Ande, D.R., 2008. Ohmic heating as an alternative food processing technology. MSc. Thesis, Food Science Institute.

Ayadi, M.A., J.C. Leuliet, F. Chopard, M. Berthou and M. Lebouche, 2004a. Continuous ohmic heating unit under whey protein fouling. Innovative Food Sci. Emerg. Technol., 5: 465-473. DOI: 10.1016/j.ifset.2004.08.001

Ayadi, M.A., L. Bouvier, F. Chopard, M. Berthou and J.C. Leuliet, 2004b. Heat treatment improvement of dairy products via ohmic heating processes: Thermal and hyrodynamic effect on fouling. Institut National de la Recherche Agronomique.

Datta, N. and H.C. Deeth, 2002. Alternatives to heat treatment: Other non-thermal technologies.

Deeth, H.C. and N. Datta, 2002. Alternatives to Heat Treatment: Pulsed Energy Technologies. In: Encyclopedia of Dairy Science, Roginski, H., J.W. Fuquay and P.F. Fox (Eds.), Academic Press, Amsterdam, ISBN-10: 0122272358, pp: 1333-1339. 
Egan, H., R.S. Kirk and R. Sawyer, 1988. Peasor Chemical Analysis of Food. 8th Edn., Reprinted Longman Scientific and Technical, UKS.

Floury, J., N. Grosset, N. Leconte, M. Pasco and M. Madec et al., 2006. Continuous raw skim milk processing by pulsed electric field at non-lethal temperature: Effect on microbial inactivation and functional properties. Lait, 86: 43-57. DOI: 10.1051/lait:2005039

Icier, F. and C. Ilicali, 2004. Electrical conductivity of apple and soucherry juice concentrates during ohmi heating. J. Food Proc. Eng., 27: 159-180.

Icier, F. and C. Ilicali, 2005. The effects of concentration on electrical conductivity of orange juice concentrates during ohmic heating. Eur. Food Res. Tech., 220: 406-414. DOI: 10.1007/s00217-004-1043-x

Icier, F., H. Yildiz and T. Baysal, 2008. Polyphenoloxidase deactivation kinetics during ohmic heating of grape juice. J. Food Eng., 85: 410417. DOI: $10.1016 /$ j.jfoodeng.2007.08.002

Kelly, A.L., N. Datta and H.C. Deeth, 2006. Thermal Processing of Dairy Products. In: Thermal Food Processing: New Technologies and Quality Issues, Sun, D.W. (Ed.), Taylor and Francis, Boca Raton, Fla., USA., ISBN-10: 1574446282, pp: 265-298.

Kong, Y.Q., L. Dong, L.J. Wang, B. Bhandari and X.D. Chen et al., 2008. Ohmic heating behavior of certain selected liquid food Materials. Int. J. Food Eng., 4: 1-146. DOI: 10.2202/1556-3758.1378

Lee, C.H. and S.W. Yoon, 1999. Effect of ohmic heating on the structure and permeability of the cell membrane of Saccharomyces cereviisae. IFT Annual Meeting. Checago.

Maroulis, Z.B. and G.D. Saravacos, 2003. Food process Design. 1st Edn., CRC Press, ISBN-10: 0824755294, pp: 536.

Muhsin, G.F., 2012. Ohmic milk pasteurizer design, manufacture and studying its pasteurization efficiency. MSc. Thesis, Food Science Department Agriculture College, Basrah University, Iraq.

Novy, M. and R. Zitny, 2005. Identification of fouling model in flow of milk at direct ohmic heating. CTU in Prague. In: Processing: New Technologies and Quality Issues, Sun, D.W. (Ed.), Taylor and Francis, pp: 265-298.

Pearson, D. and H.E. Cox, 1976. The Chemical Analysis of Food. 7th Edn., Churchill Livingstone, Edinburgh, ISBN-10: 0443014116, pp: 575.

Ryan, Y., D. Barbano, M.D. Galton, D.M. Galton and A. Rudan et al., 2000. Effects of somatic cell count on quality and shelf-life of pasteurized fluid milk. J. Dairy Sci., 83: 264-274. DOI: 10.3168/jds.S00220302(00)74873-9
Sathe, S.K. and D.K. Salunkhe, 1981. Functional properties of the great northern bean (Phaseolus vulgaris L.) proteins: Emulsion, foaming, viscosity and gelation properties. J. Food Sci., 46: 71-81. DOI: $10.1111 / \mathrm{j} .1365-2621.1981 . t b 14533 . x$

Shirsat, N., J.G. Lyng, N.P. Brunton and B. McKenna, 2004. Ohmic processing: Electrical conductivities of pork cuts. Meat. Sci., 67: 507-514. DOI: 10.1016/j.meatsci.2003.12.003

Smit, G., 2003. Dairy Processing: Improving Quality. 1st Edn., Woodhead Publishing, Cambridge, ISBN-10: 1855736764, pp: 546.

SPSS, 2001. SPSS statistical package for windows. Ver. 11.0 SPSS, Inc., Chicago.

Stanc, J. and R. Zinty, 2005. Ohmic heating and fouling of food.

Uemura, K. and S. Isobe, 2002. Developing a new apparatus for inactivating Escherichia coli in saline water with high electric field AC. J. Food Eng., 53: 203-207. DOI: 10.1016/S0260-8774(01)00158-3

Virgiliu, D.E., G. Ovidiu, G. Dan and B. Dana, 2007. New approach regarding for milk pasteuri zation from geothermal source. Case study. Fas. Manage. Technol. Eng., 6: 1-4.

Walstra, P., T.J. Geurts, A. Noomen, A. Jellema and M.A.J.S. Van Boekel, 1999. Dairy Technology: Principles of Milk Properties and Processes. 1st Edn., Marcel Dekker Inc., New York, ISBN-10: 0824746414, pp: 752.

Wang, W.C. and S.K. Sastry, 1993. Salt diffusion into vegetable tissue as a pretreatment for ohmic heating: Determination of parameters and mathematical model verification. J. Food Eng., 20: 311-323. DOI: 10.1016/0260-8774(93)90081-T

Wang, Y., T.D. Wig, J. Tang and L.M. Hallberg, 2003. Dielectric properties of foods relevant to RF and microwave pasteurization and sterilization. J. Food Eng., 57: 257-268. DOI: 10.1016/S02608774(02)00306-0

Weast, R.C. and J.A. Melvin, 1982-1983. CRC Hand book of Chemistry and Physics. 63rd Edn., pp: 2664.

Williams, S., 1984. Official Methods of Analysis. 14th Edn., Association of Official Analytical Chemists, Arlington, ISBN-10: 0935584242, pp: 1141.

Zareifard, M.R. H.S. Ramaswamy, M. Trigui and M. Marcotte, 2003. Ohmic heating behaviour and electrical conductivity of two-phase food systems. Innov. Food Sci. Emerg. Technol., 4: 45-55. DOI: 10.1016/S1466-8564(02)00088-7 